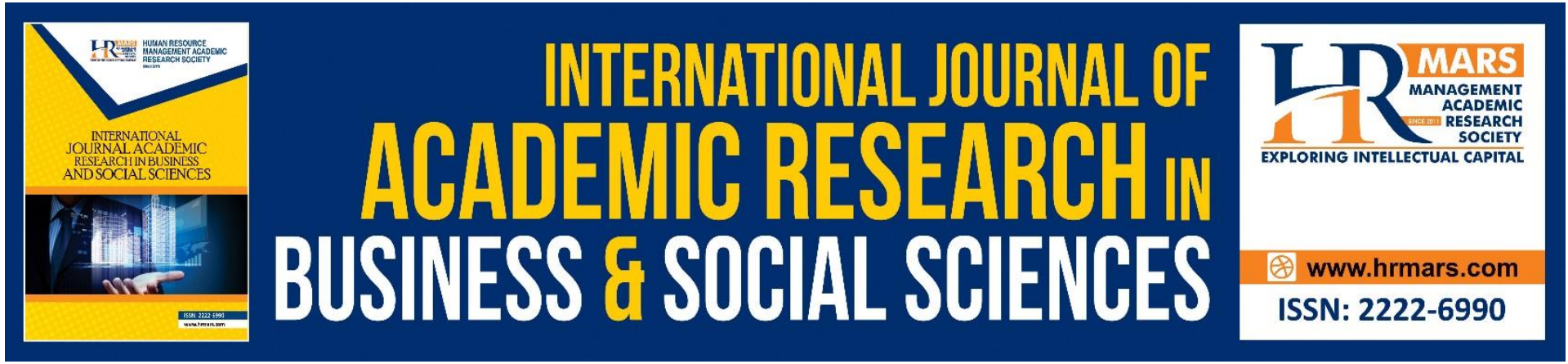

\title{
A Preliminary Study of Basic Vocal Training Methods among Malaysian Young Qari
}

Mohamad Khairul Latif, Kamarul Azmi Jasmi, Ahamad Firdaus Mohd Noor, Khairunnisa A Shukor, Rahimi Md Saad, Mohamad Sani Taib, Ishak Khairon

To Link this Article: http://dx.doi.org/10.6007/IJARBSS/v11-i7/10585

DOI:10.6007/IJARBSS/v11-i7/10585

Received: 17 May 2021, Revised: 19 June 2021, Accepted: 30 June 2021

Published Online: 23 July 2021

In-Text Citation: (Latif et al., 2021)

To Cite this Article: Latif, M. K., Jasmi, K. A., Noor, A. F. M., Shukor, K. A., Saad, R. M., Taib, M. S., \& Khairon, I. (2021). A Preliminary Study of Basic Vocal Training Methods among Malaysian Young Qari. International Journal of Academic Research in Business and Social Sciences, 11(7), 1228-1238.

Copyright: (c) 2021 The Author(s)

Published by Human Resource Management Academic Research Society (www.hrmars.com)

This article is published under the Creative Commons Attribution (CC BY 4.0) license. Anyone may reproduce, distribute, translate and create derivative works of this article (for both commercial and non-commercial purposes), subject to full attribution to the original publication and authors. The full terms of this license may be seen at: http://creativecommons.org/licences/by/4.0/legalcode

Vol. 11, No. 7, 2021, Pg. 1228 - 1238

http://hrmars.com/index.php/pages/detail/IJARBSS

JOURNAL HOMEPAGE

Full Terms \& Conditions of access and use can be found at

http://hrmars.com/index.php/pages/detail/publication-ethics 


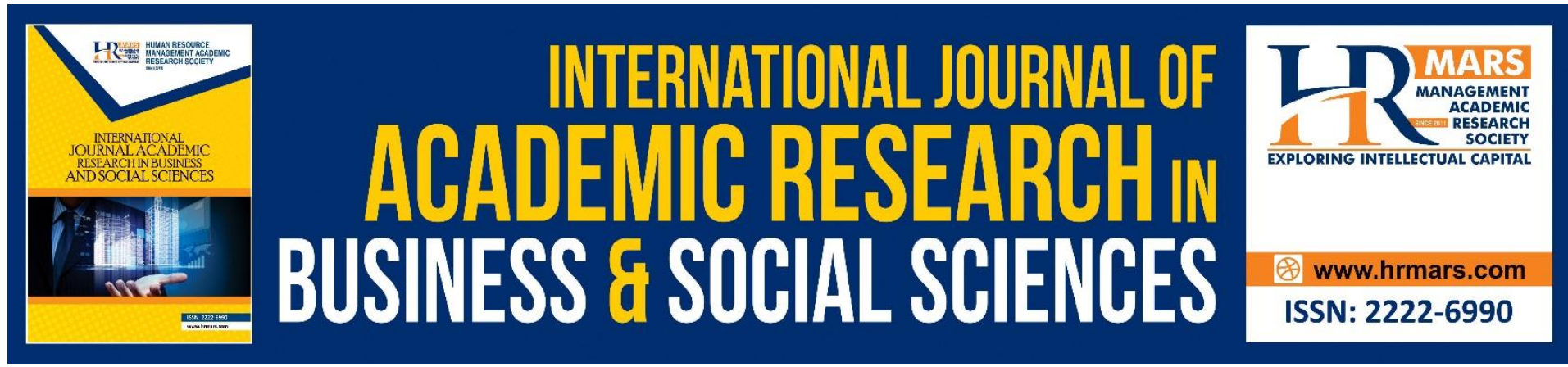

\title{
A Preliminary Study of Basic Vocal Training Methods among Malaysian Young Qari
}

\author{
Mohamad Khairul Latif ${ }^{1}$, Kamarul Azmi Jasmi ${ }^{1}$, Ahamad \\ Firdaus Mohd Noor ${ }^{2}$,Khairunnisa A Shukor ${ }^{1}$, Rahimi Md Saad ${ }^{3}$, \\ Mohamad Sani Taib ${ }^{1}$, Ishak Khairon ${ }^{1}$ \\ ${ }^{1}$ Academy of Islamic Civilisation, Faculty of Social Sciences and Humanities, Malaysia \\ Technology University, ${ }^{2}$ Academy of Contemporary Islamic Studies, Perak Branch, Malaysia \\ MARA Technology University (UiTM), ${ }^{3}$ Department of Educational Foundations and \\ Humanities, Faculty of Education, University of Malaya \\ Email: khairul1984@graduate.utm.my, qamar@utm.my, firdausnoor@uitm.edu.my, \\ dr.nisashukor@gmail.com,rahimisaad@um.edu.my,mohamadsani@graduate.utm.my, \\ us.ishak@gmail.com
}

\begin{abstract}
Reading the Quran with tarannum (in particular intonation) is encouraged in Islam. However, it requires the mastery of various skills, including vocal skills. This preliminary study focuses on exploring vocal training methods practised by young Malaysian qari and qariah in improving their tarannum al-Quran skill. This qualitative study utilised data collected from semi-structured interviews. Two participants from Tangkak District, Johor, participated in this study. The data obtained were transcribed and analysed to produce themes, subthemes and a matrix table. The findings showed that there were six elements of vocal training practised by the participants, namely 1) Self -consistent training, 2) Vocal warm-up training, 3) Tone training, 4) Burdah training, 5) Vocal control technique, and 6) Selecting the right tarannum. These six elements formed a model called the "The Young Qari Basic Vocal Training Method Model". The findings of this preliminary study indicated that the participants have implemented diverse and integrated vocal training methods to improve the quality of their vocal skills to recite the Quran. The result provides an initial overview of the vocal techniques practised by the young qari and serves as a guide to the actual study.
\end{abstract}

Keywords: Vocal Training, Young Qari, Tarannum Al-Quran.

\section{Introduction}

The teaching and learning of al-Quran delivered by the Prophet SAW can be summarised into five main approaches: tilawah, tafahum and tafsir, tatbiq, tahfiz also tarannum (Noh, Tamuri, Razak, \& Suhid, 2014). These approaches depict the diversity of Quranic knowledge, including the art of the rhythm in recitation (Nawawi, 1992). The art of tarannum refers to melodious vocal blending with the Arab sound in practising the art of tarannum to recite the 
verses of the Quran (al-Husariy, 1423H; Ibn al-Jazari, 1418H). To perform well depends on the quality of the vocal, tone control, rhythm rehashing and other matters related to vocal skills (Nik Ismail, 1998). The vocal becomes an essential element in the skill of tarannum alQuran because a good rehashing and quality vocal highlights the eminence of al-Quran through the beauty of its recitation, as mentioned by the Prophet SAW in the hadith;

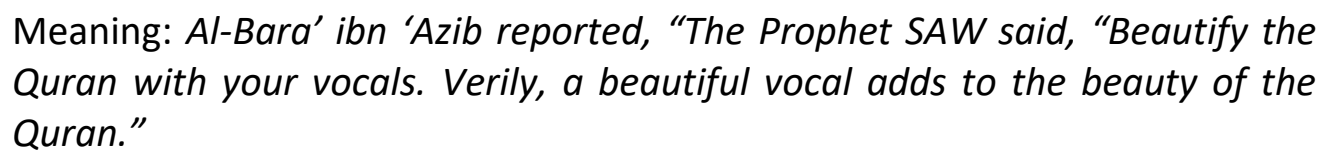

The above hadith clearly states that reciting the Quran with an excellent vocal and rhythm is demanding in Islam. The Prophet SAW also mentioned that it is also one way to ponder the meaning (Nawawi, 1992). Human is gifted with a beautiful and mesmerizing vocal, which can be processed, trained, learned and adapted suited to selected rhythm (Omar, Yakub, \& Yusoff, 2017). So, when an excellent vocal and melodious rhythm are matched with the verses of the Quran, it will certainly produce a beautiful recitation of the Quran, creating a profound effect to the soul of the reader and listener. Just as we are required to constantly strive to improve the quality of other worshipping acts such as the prayer, fasting, zakat, hajj, and others, so too are we required to constantly improve the quality of the practice of reciting the holy verses of the Quran, especially when it is related to the perfection of obligatory worshipping act, like the five daily prayers.

The increasing number of the young qari and qariah in Malaysia is a good sign of mastering Quranic recitation skills among young generations. Some of them even have won the international competition, which supersede other older qari and qariah, who are known to be skilful based on knowledge and experience. With this new encouraging phenomenon among Malaysians, it is important to explore the basic vocal training methods among these young qari and qariah, so it can be guidance to other young people to learn tarannum.

\section{Research Background}

Nik Ismail (1998) believes that the best form of reciting the Quran as Allah SWT requires is the recitation of tartil, as mentioned in surah Muzzammil verse $4 ;$ "... and recite the Quran with tartil". Based on the hadith of Rasulullah SAW, the life of the companions and the opinion of the scholars, Nik Ismail outlined four curricula that lead to the reading of tartil, which consists of; 1) tajweed, 2) fasohah, 3) tarannum, and 4) tahsin al-saut. Ibn al-Jazari $(1418 \mathrm{H})$ also mentioned these four curricula in the practice of reading the Quran.

First, the tajweed curriculum. In general, it refers to knowledge related to the method of pronouncing the nature of letters and their makhraj, the recitation of kalimah, mad, ghunnah, izhar, idgham, tanwin, sukun, the resam uthmani method and the knowledge of qiraat (al-Husari, 1970). In the early days of Islam, the knowledge of tajweed has not been compiled as today. Instead, its practice has taken place through the teaching of the Prophet SAW to the Companions. As it is one of the core knowledge, it is essential to ensure that every word and verse of the Quran is read as it was revealed (As-Suyuthi, 2008).

The second curriculum is fasohah, which refers to knowledge of lahjah, the preservation of letters, lines, sentences, sentence structures and waqaf ibtida'. These parts 
of the knowledge of tajweed serve to preserve the recited structure of the verses from any minor (lahan khafi) or major mistakes (lahan jali). A slight change occurs in the structure of the words or verses of the Quran changes its meaning (Ibn al-Jazari, $1418 \mathrm{H}$ ).

The third is the tarannum curriculum. This knowledge relates to blending rhythm from the Arab songs such as Bayyati, Soba, Nahwand, Hijaz, Rast, Sikah, Jiharkah and others. In addition, people who acquire this knowledge blends the Arab sound of reciting the Quran, just as mentioned by the Prophet SAW.

The fourth is the tahsin al-saut curriculum, which refers to the knowledge related to vocal skills such as vocal control methods, tone, rhythm, burdah, vocal properties, and vocal processing techniques that are interrelated with the art of tarannum al-Quran. These skills produce beautiful recitation, highlighting the perfection of the verses in the Quran (Nik Ismail, 1998; Zakaria, 2011). The relationship among the mentioned four curricula is illustrated in Figure 1: The Tartil Integrated Model.

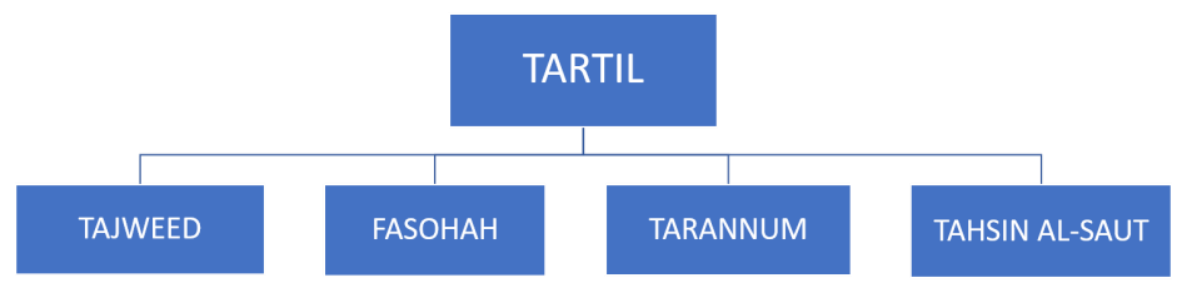

Figure 1: The Tartil Integrated Model Source: Ibrahim (2010)

Based on this Integrated Tartil Model, tahsin al-saut becomes an essential element towards achieving the standard of tartil recitation as desired by Allah SWT. This model also explains that the knowledge of tajweed and fasohah is the core knowledge in the skill of reciting the Quran and implementing it is obligatory, while reciting the Quran with tarannum and a good vocal without violating the laws of tajweed is a Sunnah (alHusariy, 1423H; al-Syafi'i, 1983; Nawawi, 1992; Ibn Battal, 2000). To practice the skill of reciting tarannum effectively, one needs to rehash the rhythm of tarannum to suit his vocal by fulfilling the laws of tajweed and fasohah. All skills are simultaneously blended in one recitation.

It should be noted that not all songs can randomly be chosen to recite the verses of the Quran. Instead, only those songs agreed and practised by the ahlul Quran are allowed. Apart from the demands of syara', it also prevents ghuluw (violating the tajweed) and using the songs of the fasiq (Ibrahim, 2010). There are two streams of tarannum practised by the Muslims; the Hijazi stream and the Misri stream. Recently, the Misri stream is more dominant and widely practised, especially among qari, qariah and students of tarannum al-Quran in Malaysia (Abdullah, Ishak, Mohamad, \& Hasin, 2014; Isa, Ibrahim, \& Daud, 2016; Omar, 2016; Omar, Yakub, et al., 2017; Abbas, 2017; Sakat, \& Mohammad, 2019).

Tarannum Misri consists of seven types of core songs, namely Bayyati, Soba, Nahwand, Hijaz, Rast, Sikah and Jiharkah songs, while the branch songs are A'jam, Kurdi, 
Shuri, I'raqi, Husaini, U'shaq, Kard Kurd, Bustanjar, Nakriz and Mahur (Isa et al., 2016). Each type of tarannum has a different character of sounds that is highlighted through the tone, melody, rhythm and the rhythm determined by the vocal of a qari or qariah (Nik Ismail, 1998). The tone is the main feature of tarannum. It is divided into four, namely the tones of qarar (low), nawa (medium), jawab (high) and jawab al-jawab (highest) (Isa et al., 2016; Nik Ismail, 1998). The tone skills ensure that one can demonstrate each tarannum perfectly.

Tarannum consists explicitly of an arrangement of several beats called harakat. Each harakat results from a combination of several short rhythms called qit'ah and ends with a closing rhythm known as mahattah. All these skills are manifested by the sound of the reader's vocal and decorated by chanting (burdah). Burdah is categorized into two, namely the original burdah (natural vocal vibration) and burdah sinai' (arranged vocal vibration). Apart from that, there are other vocal skills, namely the skills of ascending tone (salalim suu'd), descending tone (salalim nuzul), intentional inconsistent rhythm (ihtilal al-lahn) and combining two-song rhythms in one harakat (waslah al-mumasalah) (Nik Ismail, 1998; Zakaria, 2011; Isa et al., 2016; Abbas, 2017; Latif, Jimaain, \& Jasmi, 2020).

Everything explained above are the forms of vocal skills contained in the knowledge of tarannum. However, compared to the tajweed skills, the tarannum skill has its challenges because it involves the variations of rhythm, high and low tone movements, the slow and long reading tempo of a verse (Afrillia, Mawengkang, Ramli, \& Putra Fhonna, 2017). Therefore, the question arises as to how the method of vocal training is done, especially by the young qari and qariah, which allows them to master the skill of tarannum al-Quran well.

Therefore, an in-depth study needs to be done on these talented young qari and qariah to explore how this vocal training method is practised. Although previous studies explain the learning, teaching and practice of tarannum by Malaysian qaris and qariah, the researchers found that there is still a lack of studies explaining how this vocal skills training is implemented. The study on young people skilled in tarannum is not widely explored, while this is a positive phenomenon in Malaysian society nowadays. Therefore, this preliminary study was conducted to obtain preliminary data related to this matter.

\section{Research Objective and Question}

This study was conducted to explore the methods of vocal training practised by young qari and qariah in improving the quality of tarannum al-Quran. Therefore, the research question raised is how do young qari and qariah practise vocal training in improving the quality of their tarannum al-Quran?

\section{Research Methodology}

This study is a complete qualitative study using a case study. The semi-structured interview method was used as the primary method in data collection. The case study design was chosen because it allows the researcher to focus and carry an in-depth manner about a phenomenon in real situations (Yin, 2017). Participants selection for this study involved two individuals, as recommended by Creswell (2012), which is to select participants who have characteristics similar to the actual population, easy to contact and live at a suitable place to support the in-depth study. For this study, both participants were selected from Tangkak, Johor, the district where the researchers resided. 
The first participant was selected through a purposeful sampling technique based on specific criteria set by the researchers. 'Rich' data can be collected from those who have indepth knowledge of the phenomenon to be studied (Creswell, 2012; Palinkas et al., 2015). The participants, as decided by the researchers of this study, aged between 18 to 25 years old, won the al-Quran recitation district competition as organized by the district Islamic Department, and have participated in the Al-Quran Recitation Testing Council (MPTQ) at the Johor state level as organized by the Johor Islamic Religious Department (JAIJ) more than three times. The gender of the participants was not considered in this study. Meanwhile, the snowball sampling technique was used in the selection process of the second participant, where the first participant himself proposed the second participant who matched the criteria decided for this study (Johnson, 2014). Thus, the second participant served as the secondary source of data which validated and supported the data obtained from the first participant.

The following criteria mention the characteristics of the participants:

Participant 1:

- a 21-years-old young qariah (YQ) from Tangkak district

- Pursuing studies in law at the International Islamic University of Malaysia (IIUM).

- Won the MPTQ at the Tangkak district level for the years 2019, 2020 and 2021

- represented the Tangkak district in the MPTQ at the Johor state level three times.

Participant 2:

- the tarannum teacher (TT) of participant 1

The semi-structured interview method was the primary method used in this study. This process was conducted based on a set of interview protocols that have been modified from Mohd Noor (2017) that aimed to explore the vocal training methods practised by the participants. The researchers conducted face-to-face interviews. Questions were asked inductively, from general questions to more specific and detailed questions. The interview sessions were recorded using an MP4 vocal recorder. These processes were performed as suggested by qualitative scholars (Merriam, 2002; Creswell, 2012; Yin, 2017). The recorded interviews were transcribed into narrative data and analysed to produce the initial findings using N'vivo 12 software.

\section{Research Findings}

A theme of the study has been identified from the analysis. The participants have implemented a form of integrated vocal training method to improve the skills and quality of the vocal in their tarannum recitation. The theme of the study is explained in Table 1.

Table 1: Theme Formation from the Analysis

\begin{tabular}{|l|c|l|l|}
\hline No & Theme & YQ, 2020 & TT, 2020 \\
\hline 1 & Basic Vocal Training Method & 5 & 3 \\
\hline
\end{tabular}




\section{Basic Vocal Training Method}

The data show that the theme of vocal basic training method contains six elements, which include self-consistent training, vocal warm-up training, tone training, burdah training, vocal control techniques and tarannum selection, as described in the following Table 2 .

Table 2: Elements of Basic Vocal Training Method

\begin{tabular}{|r|l|l|l|}
\hline No. & Elements & $\mathrm{YQ}, \mathbf{2 0 2 0}$ & $\mathrm{TT}, \mathbf{2 0 2 0}$ \\
\hline 1. & self-consistent training & $\mathrm{X}$ & $\mathrm{X}$ \\
\hline 2. & vocal warm-up training & $\mathrm{X}$ & - \\
\hline 3. & tone training & $\mathrm{X}$ & $\mathrm{X}$ \\
\hline 4. & burdah training & $\mathrm{X}$ & - \\
\hline 5. & vocal control techniques & $\mathrm{X}$ & - \\
\hline 6. & tarannum selection & - & $\mathrm{X}$ \\
\hline
\end{tabular}

\section{Discussion}

The first element identified from the finding is self-consistent training. As participant 1 mentioned;

"So among the forms of vocal training that I ... that I have been practising of course... for sure... consistently training ..."

(YQ, 2020, p.7)

This self-consistent training means self-repeated tarannum training on her own, as the YQ explained;

"Usually, I train a lot by myself..."

(YQ, 2020, p.4)

The TT also confirmed this practice by stating;

"For me, she has done much practising... listening... self-practising..." (TT, 2020, p.5)

In self-regulation theory, it is explained that students play a role in systematically activating their cognitive, behavioural, and affective aspects of the self to achieve their learning goals (Brophy, 1998). The method of drilling, tasmi' and tashih in learning al-Quran skills is a necessary process that strengthens the process of talaqqi musyafahah with teachers (Tamuri, Ismail, \& Jasmi, 2012). In the context of vocal skills, constantly practising tarannum on their own enables a person to sharpen, improve the quality of a person's vocal gradually.

The second element is the vocal warm-up exercise. This process is conducted before starting the tarannum recitation exercise, based on the YQ's statement;

"If with Hajah before this, when practising with her, before we started practising, I must practice Do Re Mi first .. aaaa practice Do Re Mi first for toning... mmmm that's for the tone of vocal..." (QM, 2020, p.8).

The YQ did the vocal warm-up exercise in order for the vocal cavity to be warmed up first and be in a better state before performing the tarannum reading. This 
exercise prevents vocal damage such as hoarseness or other vocal problems. Vocal warmup exercises are also practised by skilled qari and qariah, such as chanting qasidah (Omar, Ismail, Rahman, \& Azman, 2017). Based on the researchers' experience, certain tausyikhs or naghams in the form of prayers or Islamic poems are also suitable to be practised as one of the methods to warm up the vocal cord before starting the tarannum recitation training.

The third element is tone training. The YQ emphasizes the tone training through his statement;

"So my way is when I practice... I will raise the tone a little higher... usually higher than the normal tone I always do..., so that is actually to practice my vocal so that it becomes stronger and familiar with high tones."

(QM, 2020, p.7)

The YQ admitted that the tone elevation exercise improved his vocal ability and endurance, as high tones are challenging to master. Even the TT has confirmed through her statement;

"It is just that she has difficulty to master the higher ones, but... it is the skills... she is good at blending the tone..."

(TT, 2020, p.5)

The tone of voice in the knowledge of tarannum is also known as tabaqat voice. The skill of tabaqat plays a role in livening up the rhythm of the tarannum recitation so that it is not monotonous, distinguishing between harakat in a tarannum (Abdullah et al., 2019). Tone training improves the level of ability, endurance, quality and stability of the voice. A good reader is the one who can chant the four tabaqat voices (qarar, nawa, jawab and jawabul jawab) comfortably, perfectly and confidently (Abdullah \& Daud, 2018).

The fourth element is the vocal control technique, as the YQ has stated; "So, during the practice, we must also practice the voice control technique." (YQ, 2020, p.7)

This statement clarifies that during the tarannum recitation, the vocal projection must be controlled, not too excessive, using particular techniques suitable for every tone movement. Among the vocal control techniques to recite the Quranic verses include the soft and hard techniques, vocal cord handling technique, sound channelling technique and breath control technique (Omar, Yakub, et al., 2017). These techniques are essential in controlling the vocal movement during tarannum recitation, reaching the right note and tuneful.

The fifth element is the practice of burdah. The YQ explained; "When I practice, I like imitating the recitation of the qari and qariah from YouTube, for example, so from there I practice burdah, and I follow, until I can successfully do it." (QM, 2020, p.7)

Burdah or sound vibration is one of the essential characters of sound in tarannum. Burdah serves to beautify each harakat of tarannum. Therefore, it needs to be arranged carefully and wisely by qari in each harakat (Omar, Ismail, et al. 2017; Abdullah \& 
Daud, 2018). The arrangement of burdah in a harakat should consider tone suitability, tajweed, fasohah and the meaning of the verse. Improper arrangement of burdah will affect the quality of one's tarannum recitation art.

The sixth element is to choose the tarannum according to the suitability of the voice. The TT emphasizes this point as he mentioned;

"Maybe she needs guidance for the high and loud melody like Rast, but Jiharkah suits her well, very suitable... if it is like during berzanji, she tunes in the Rakbi song, which is very suitable for her...but like Rast, which involves loud and high tone, she needs more training...".

(TT, 2020, p.5)

Based on the statement, a qari or qariah needs to know the characteristics, nature and the ability of their voice as a guide to select the right tarannum suitable for voice. It affects the quality of the tarannum, as the seven Misri tarannum have different rhythmic characters such as mournful, sad, moderate, happy, firm, lively and high-pitched (Zakaria, 2011; Omar, Yakub, et al., 2017). For example, the nature and ability of the voice between men (qari) and women (qariah) are usually different, some can be high-pitched, and some are not, as well as low-pitched. Therefore, understanding the nature and level of voice ability itself is an essential process in learning the tarannum of the Quran. Emphasizing this element can help the qari and qariah focus on the form of training required according to the situation and ability of their respective voices.

\section{Implication and Suggestion}

The findings of this preliminary study have formed a basic model that can be considered the Model of Basic Vocal Training Method of the Young Qari in mastering tarannum al-Quran skills. This model, along with its elements, is illustrated in the following Figure 2.

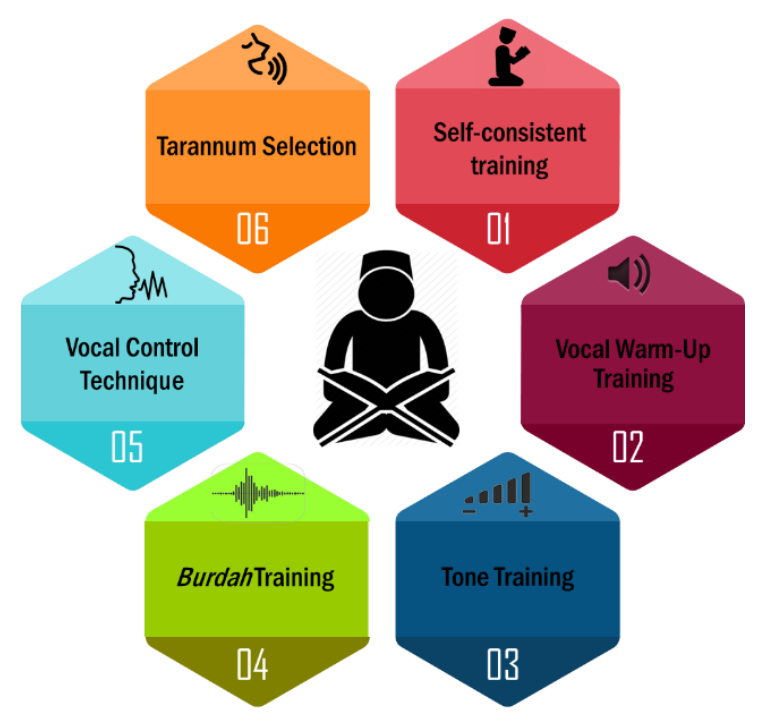

Figure 2: Model of Basic Vocal Training Method for the Young Qari

This model explains how the participants in this study performed a variety and integrated training methods to improve vocal skills to enable them to master the skills 
of tarannum al-Quran well. The elements in this model can be an essential guide for understanding and training the tarannum al-Quran, particularly on mastering the vocal skills, which are more clearly and systematically.

\section{Summary}

This study has provided preliminary information on the basic vocal training methods that are the core to the mastery of tarannum skills among young qari and qariah. In this article, the researchers have discussed the background, objective, methodology, and findings on basic vocal training methods obtained from the participants. These findings have produced preliminary data that form the "Basic Vocal Training Method Model for the Young Qari", which is presented in the implications section of the study. Practising the method of vocal training in a focused manner is vital because vocal skills are parallel and inseparable from the learning of the tarannum of the Quran itself. It can also be understood that the higher the skill and quality of one's vocal will be, the better the quality of the art of reciting the tarannum al-Quran. It can be achieved more quickly and effectively through integrated training, as discussed.

\section{References}

Abbas, M. R. G. (2017). Persepsi Murid Terhadap Minat, Amalan dan Persekitaran Pembelajaran Serta Amalan Pengajaran Guru Tarannum al-Quran. Master Thesis, Universiti Kebangsaan Malaysia, Bangi.

Abdullah, W. H. W., \& Daud, M. (2018). Ketokohan Sheikh Mustafa Ismail dan Sumbangannya dalam Dunia Tilawah Al-Quran Secara Bertarannum. Albasirah Journal, 8(2), 89-97.

Abdullah, W. H. W., Ishak, H., Mohamad, S., Sakat, A. A., \& Mohammad, W. F. R. W. (2019). Ketokohan Haji Hasan Musa dalam Seni Tarannum di Malaysia dan Kaedah Tilawah alQuran al-Lahjah al-Arabiyyah. BITARA International Journal of Civilizational Studies and Human Sciences, 2(3), 93-102.

Afrillia, Y., Mawengkang, H., Ramli, M., \& Fhonna, P. R. (2017). Performance Measurement Of Mel Frequency Central Coefficient (MFCC) Method In Learning System Of Al-Quran Based In Nagham Pattern Recognition. Journal of Physics Conference Series.

Al-Husari, M. (1970). Ahkam Qira'ah al-Quran al-Karim. Kaherah: Dar al-Thurath.

Al-Husariy, M. K. (1423H). Ma'al Quran al-Karim, . Qahirah: Maktabah al-Sunnah.

Al-Syafi'i, A. A. M. B. I., al-Imam. (1983). al-Umm (Vol. 6). Beirut: Dar Al-Fikr.

As-Suyuthi, J. (2008). al-Itqan fi 'Ulum al-Qur'ān. Bairut: ar-Risalah Nashirūn.

Brophy, J. (1998). Motivating students to learn. New York: McGraw-Hill.

Creswell, J. (2012). Education research: planning, conducting, and evaluating quantitative and qualitative research 4th edition. University of Nebraska: Lincoln.

Hasin, A. (2014). Tatawwur Fan Tarannum Fi Malizia: Dirasah Tarikhiyyah wa Ilmiyyah. Journal of Ma'ālim al-Qur'ān wa alSunnah, 9(10), 180-202.

Ibn al-Jazari, S. A.-D. A. B. B. A. B. M. (1418H). Syarah Tayyibah al-Nasyr fi al-Qiraa'at al-Asyr, Beirut: Dar al-Kutub al-'llmiyyah,.

Ibn Battal, A. B. K. B. A. A.-M. (2000). Syarh Sahih al-Bukhariy (Vol. 10). Riyadh: Maktabah alRusyd.

Ibrahim, M. L. (2010). Tarannum Al-Quran Melalui Tariq Al-Syatibi: Kajian Terhadap Pengamalannya Dalam Kalangan Qari-Qari Kelantan Ke Majlis Tilawah Al-Quran Peringkat Kebangsaan Malaysia Antara Tahun 1990-2005. PhD Thesis, Universiti Malaya, Kuala Lumpur. 
Isa, K., Ibrahim, M. L., \& Daud, M. (2016). Tan Sri Dato'Haji Hassan Azhari. Albasirah Journal, 6(1), 31-47.

Johnson, T. P. (2014). Snowball Sampling: Introduction. Wiley StatsRef: Statistics Reference Online.

Latif, M. K., Jimaain, T., \& Jasmi, K. A. (2020). Competence and Method of Teaching Tarannum Al-Quran Among Teachers of Special Class on Reading and Memorizing Al-Quran Skill (KKQ) in Johor. 3rd International Conference on Research of Educational Administration and Management (ICREAM 2019).

Merriam, S. B. (2002). Assessing and evaluating qualitative research. Qualitative research in practice: Examples for discussion and analysis, 1, 18-36.

Noor, M. A. F. (2017). Pensyarah Cemerlang Pendidikan Islam di Politeknik: Satu Kajian Kes. PhD Thesis, Universiti Teknologi Malaysia, Johor.

Ismail, N. J. (1998). Qawaid Tarannum (1 ed.). Kuala Lumpur: Darul Fikir.

Noh, M. A. C., Tamuri, A. H., Razak, K. A., \& Suhid, A. (2014). The Study of Quranic Teaching and Learning: United Kingdom Experience. Mediterranean Journal of Social Sciences, 5(16), 313-318.

Omar, N. (2016). Perkembangan Pengajian Tarannum Al-Quran Di Terengganu Pada Zaman Pra-Merdeka Sehingga Tahun 2014. Jurnal Islam dan Masyarakat Kontemporari, 13(2), 105-117.

Omar, N., Ismail, F. Z., Rahman, T. A., \& Azman, N. N. N. (2017). Faktor-faktor Kejayaan Qari Negeri Terengganu dalam Kesenian Lagu Al-Quran. Jurnal Sains Insani, 2(1), 35-41.

Omar, N., Yakub, M., \& Yusoff, Z. M. (2017). Sumbangan Dato' Hajah Rogayah binti Sulong Dalam Pengajaran dan Pembelajaran Tarannum Al-Quran (Contribution of Dato'Hajjah Rogayah Binti Sulong in Teaching and Learning of Tarannum al-Quran). Journal of AlTamaddun, 12(2), 73-85.

Palinkas, L. A., Horwitz, S. M., Green, C. A., Wisdom, J. P., Duan, N., \& Hoagwood, K. (2015). Purposeful sampling for qualitative data collection and analysis in mixed method implementation research. Administration and policy in mental health and mental health services research, 42(5), 533-544.

Tamuri, A. H., Ismail, M. F., \& Jasmi, K. A. (2012). Komponen Asas untuk Latihan Guru Pendidikan Islam [Basic Components for Islamic Education Teacher Training]. Global Journal Al-Thaqafah, 2(2), 53-63.

Yin, R. K. (2017). Case study research and applications: Design and methods: Sage publications.

Zakaria, F. I. (2011). Penilaian perlaksanaan pengajaran dan pembelajaran tarannum al-Quran Kelas Khas Kemahiran Membaca dan Menghafaz al-Quran (KKQ) di Selangor. Master Thesis, Universiti Kebangsaan Malaysia, Bangi. 